\title{
GOVERNMENTS-IN-EXILE AND THE EFFECT OF THEIR EXPROPRIATORY DECREES
}

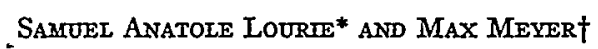

\section{GOVERNMENTS-IN-EXILE AND THEIR IEGISLATIVE POWER}

1 HE present war has brought about a situation in which sovereigns and high governmental officials of countries occupied by the enemy, having escaped from occupied territory, continue to exercise governmental functions on British soil with the assent of the British Government.

Though some of these foreign authorities, commonly referred to as governments-in-exile, suffer from more or less serious congenital ${ }^{2}$ or postnatal ${ }^{3}$ defects, they have been recognized as de jure governments of the respective countries by the United Nations and by several neutral countries. For the purposes of this article it is assumed that these recognitions have a rehabilitative effect on the legal well-being of these governmental bodies, and that the governments-in-exile can generally exercise in the matter of expropriation the same powers as if they were on their own soil. Though many objections may be raised against this assumption, a discussion thereof would, for the time being, be futile, since such a discussion, being detached from reality, runs counter to the policy of the recognizing states as expressed by the acts of recognition. ${ }^{4}$

With respect to the governments-in-exile, two kinds of recognition have to be distinguished: one is the continuing recognition of the government existing in the country immediately preceding the occupation, and of their successors; and the other, recognition ab origine of a newly created governmental authority on Allied soil..$^{5}$ While the international obli-

* Formerly of the Estonian Bar.

$\dagger$ Formerly of the Netherlands Bar.

${ }^{x}$ See Diplomatic Privileges (Extension) Act, x94I, 4 \& 5 Geo. VI, c. 7.

$=$ E.g., the Czechoslovak Government.

3 E.g., the Belgian Government.

${ }_{4}$ Cf. Justice Shientag in Anderson v. N.V. Transandine Handelmaatschappij, 28 N.Y.S. 2d 547, 55I (r94I), considering the circumstance of the promulgation of the Royal Netherlands Decree of May 24, 1940, in London rather than at The Hague to be immaterial in view of the fact that the American Government continues to recognize the Netherlands Royal Government temporarily residing in London.

$s$ E.g., the Czechoslovak Government. 
gations of a government-in-exile of the first type cannot be legally repudiated by their states, ${ }^{6}$ the obligations of the governments of the second type have to be explicitly or by implication assumed by the states which they purport to represent.

It is generally accepted that control over the territory of the country (or at least a substantial part of it) is a prerequisite to recognition. However, in the event of enemy occupation of its territory, this requirement is suspended, and recognition of the exiled government may be continued. Furthermore, recognition may be extended to newly created governments without territory and without continuity. ${ }^{7}$ The effects of recognition of governments-in-exile vary somewhat from the effects of recognition under normal circumstances. The absence of dominion over their own territories and their presence on foreign soil are dominating factors which condition this divergence. This is exemplified by various statutes enacted in Great Britain in order to enable the governments-in-exile to exercise governmental functions. ${ }^{8}$ Without such enabling acts the governments-in-exile could perform no function on foreign territory outside of those activities pertaining to matters commonly embraced by the term "external affairs."

Whereas the recognition of a government generally entails the sacrosanctity of acts of state ${ }^{9}$ of this government, the question arises whether the same sacrosanctity attaches to acts of state of governments-in-exile. The answer to this question seems to a large extent to depend on the circumstance that the governments-in-exile bear the imprint of the present state of emergency. Hence the scope of their governmental activities is predetermined thereby. In general, it may be asserted that the govern-

${ }^{6}$ Cf. Guaranty Trust Co. v. United States, 304 U.S. I26, I37-I38 (I938); Russian Government v. Lehigh Valley R. Co., 293 Fed. I35, I37-r 88 (S.D.N.Y. x923); Lehigh Valley R. Co. v. State of Russia, 2r F. 2d 396, 400 , 40 r (C.C.A. 2d 1927); I Moore, International Law Digest $\S 96$ (I906); I Hackworth, Digest of International Law 387-392 (1940); Borchard, Diplomatic Protection of Citizens Abroad 202 ff. (I9I5).

7 As to the nature of the recognition, there are two schools of thought: the prevailing one considers the recognition to be merely a declaration of the legal existence of the state or government; the other regards it as constitutive. Cf. Kelsen, Recognition in International Law (Theoretical Observations), 35 Am. J. Int. L. 605 (I94x), distinguishing between recognition as a legal and political act; the first to be constitutive and the second merely declaratory. Contra: Brown, The Effects of Recognition, 36 Am. J. Int. L. 106 (1942); Borchard, Recognition and Non-recognition, $36 \mathrm{Am}$. J. Int. I. ro8 (I942). Without taking sides in this controversy, we wish to point out that in the case of recognition of newly established governmentsin-exile the constitutive effect of recognition is conspicuous.

${ }^{8}$ Diplomatic Privileges (Extension) Act, I94I, $4 \& 5$ Geo. VI, c. 7; The Allied Powers (Maritime Courts) Act, I94I, 4 \& 5 Geo. VI; The Allied Forces Act, I940, 3 \& 4 Geo. VI, c. 5 I.

9 Mann, The Sacrosanctity of the Foreign Act of State, 59 L. Q. Rev. 42 and ibid. I55 (1943). 
ments-in-exile are well aware of their inherent disabilities. They try to limit their acts to the implementation of their organizational and functional structure, and to the prosecution of the war in all its aspects-military, economic, and psychological-and to meet extraordinary conditions created by the emergency. ${ }^{\text {IO }}$

In enacting these measures, the governments-in-exile have not and indeed could not strictly adhere to constitutional requirements. ${ }^{\text {Ix }}$ Though some modern constitutions envisage extraordinary situations created by war or other national emergencies, ${ }^{\mathrm{I2}}$ the present war has produced conditions which defy even the boldest imagination of framers of constitutions. Constitutional checks and balances devised for ordinary conditions are unworkable in times of emergency. Moreover, the provisions, intended to deal with catastrophes within the contemplation of the constitutions, are not adequate to handle a situation where the very existence of state and nation is at stake.

It is obvious that a sovereign must take all measures necessary for the preservation of state and nation, ${ }^{x 3}$ thereby acting in accordance with constitutional limitations in so far as they can objectively be complied with; particularly in view of the fact of belligerent occupation. To condemn the government to impotence by fettering it with requirements which are impossible of observance (e.g., functioning on national soil ${ }^{14}$ or convocation of Parliament) would be tantamount to the extension of constitutional doctrine "with relentless disregard of consequences to a 'dryly logical ex-

to Oppenheimer, Governments and Authorities in Exile, 36 Am. J. Int. L. 568, 584-586 (1942). Cf. also Landheer, The Legal Status of the Netherlands, 4I Mich. L. Rev. 644 (r943), and especially the Appendix at 654 containing the titles of the decrees of the Netherlands Government-in-Exile.

xr In In re Amand (No. I), [I94I] 2 K.B. 239, the King's Bench Division held valid the Netherlands Royal Decree concerning conscription of Netherlands nationals promulgated in London, in the teeth of the provision of Article $2 x$ of the Netherlands Constitution that "in no circumstances can the seat of the government be moved outside the realm of the Kingdom." See also Fields v. Predionica i Tkanica A.D. and Yugoslav Government, 265 App. Div. I32 (Ist Dep't, 1942), 37 N.Y.S. 2d 874 (r942), reversing 35 N.Y.S. 2d 408 (r942), leave to appeal denied 265 App. Div. I000 (r943). But cf. McNair, Municipal Effects of Belligerent Occupation, 57 L.Q. Rev. 33, 68 (I94I).

\2 See, for instance, the Polish Constitution, Art. 79, \$2.

${ }^{13}$ See In re Amand, supra, note II, and Dicey, Introduction to the Study of the Law of the Constitution 4I2, 4I3 (9th ed. by E.C.S. Wade I94I).

${ }^{34}$ "It would lead to the conclusion that the invasion of the Netherlands in May, r940, not only drove out the Government, but made it impossible henceforth for any steps to be taken by the Government as such to recover their violated territory or to help their nationals." In re Amand, [I94I] 2 K.B. 239, as reported in the Czechoslovak Yearbook of International Law $I_{76}$ (I942). 
treme." "' ${ }^{55}$ This does not mean, however, that the governments, in adopting measures, should be free from inhibitions and restraints. ${ }^{16}$ The international cataclysm which brought into motion these emergency powers of the government defines at the same time their boundaries, i.e., their measures should be reasonably adapted to meet the various exigencies resulting from this crisis.

This leads us to the following question: Should the government-in-exile be the sole and final arbiter of the "reasonableness" of its own legislative acts? Under normal parliamentary procedure the legislature or the judiciary is in a position to control by various means the actions of the executive branch. The absence of controlling organs entails the danger that persons in power may develop a tendency towards arbitrariness and capriciousness. However, effective political and legal curbs still remain. We have here in mind, above all, the restraining effect of public opinion as manifested by their own nationals within or without occupied territories, and public opinion in Allied countries. The latter may even be the motivating cause for the withdrawal or withholding of recognition or for the extension of limited recognition only.

A restraining factor of a legal nature may be found in the necessity for the governments-in-exile to have their acts ratified, approved, or confirmed after the liberation of their countries. The form of the ratification, approval, or confirmation will depend on the origin of the government-inexile, whether a continuation of the original government or a government de novo; on the respective constitutions; on existence or absence of enabling acts; $;{ }^{17}$ and on the very nature of the governmental acts themselves. A further legal curb may be supplied by the courts when they are approached to decide controversies involving the effect of the acts of the governments-in-exile. ${ }^{\text {.8 }}$

Is Judge Cardozo in Hynes v. N.Y.C.R.R. Co., 23 I N.Y. 229, 235, I3I N.E. 898,900 (r92r) speaking about dangers of "a jurisprudence of conceptions."

${ }^{26}$ But cf. Oppenheimer, supra, note 10 , at 582,583 .

${ }^{27}$ See, for instance, the act of the Norwegian Storting granting to the King at its convention on Norwegian territory in Elverum on April 9, I940, "the widest authority to take the decisions and resolutions which are necessary in respect of the protection of the interests of the Kingdom until the Storting can be again summoned to a fresh meeting." Documents on international affairs (Norway and the War, September, I939-December, 1940), edited by M. Curtis and issued under the auspices of the Royal Institute of International Affairs (r94r), cited in Legislation in Exile: Norway, 24 J. Comp. Leg. \& Int. L. I25 (I942). The Norwegian decrees are designated as "provisional," clearly indicating thereby that the people of Norway will be called upon to ratify or cancel.

${ }^{28}$ Cf. In re Amand (No. 2), [r942] I K.B. 445 . 


\section{EXPROPRIATORY DECREES AND THE SITUS OF INTANGIBLES}

Among the various legislative measures of the governments-in-exile, expropriatory decrees are particularly conspicuous, and have given and will continue to give rise to numerous litigations. The crux of these litigations is the question whether extra-territorial effect should be accorded to these decrees, and if so, to what extent. This problem will be discussed with an eye primarily to the public and private international law rules as applied in the United States and Great Britain. It is usually created by the following typical situations:

I. The original depositor with an American bank sues the bank to recover his deposit or the original obligee of an American obligor sues the latter for performance. ${ }^{\text {9 }}$

2. A depositor deposits moneys or securities with a bank in occupied territory, and this bank at the depositor's instructions redeposits the moneys or securities with an American bank. The redeposit can assume the form of a sub-deposit or be intermingled with the general deposit in the name of the foreign bank. The depositor now sues the American bank directly to recover his moneys or securities by impressing a trust. ${ }^{20}$

3. A customer instructs his bank or broker in territory later occupied by the enemy to buy United States dollars or securities, with the express or implied understanding that the same shall be redeposited with an American firm; for the rest, the situation is similar to that described under paragraph $2 .^{2 x}$

4. A creditor of a foreign national attaches the latter's American assets. ${ }^{22}$

5. Heirs, distributees, or legatees of a foreign national claim their shares or interests in the American assets of the decedent's estate. ${ }^{23}$

6. The expropriating government claims a share or interest in the estate of a decedent who died in the United States and whose heirs, disCt.).

s9 Valk v. Reilly Tar \& Chemical Corp., N.Y.L.J., March 10, r943, p. 953, col. 3 (N.Y. Sup.

20 Birnbaum v. Irving Trust Co. (Amsterdamsche Liquidatiekas N.V.), N.Y.I.J., Aug. I4, rg43, p. 3I5, col. 2 (N.Y. Sup. Ct.). For analogous situations, but ones not involving decrees of governments-in-exile, consult Feuchtwanger v. Central Hanover Bank \& Trust Co., 288 N.Y. 342, 43 N.E. 2 d 434 (r942); Bercholz v. Guaranty Trust Co., N.Y.L.J., Aug. II, I943, p. 290 , col. 5 (N.Y. Sup. Ct.); Geismar v. Bellamy, N.Y.L.J., Aug. 24, I943, p. 377, col. 5 (N.Y. Sup. Ct.), all involving French law.

${ }_{21}$ Van der Veen v. Amsterdamsche Bank, 178 Misc. 668, 35 N.Y.S. $2 d 945$ (x942).

${ }_{22}$ Anderson v. N.V. Transandine Handelmaatschappij, 289 N.Y. 9, 43 N.E. 2 d 502 (x942); Gruenbaum v. N.V. Oxyde Maatschappij voor Ertsen en Metalen, N.Y.L.J., Aug. 27, 194I, p. 439, col. 7 (N.Y. Sup. Ct.); Duestervald v. Ladewig, N.Y.L.J., Jan. 15, I942, p. 215, col. 2 (N.Y. Sup. Ct.).

${ }^{23}$ Estate of Emanuel Kahn, 38 N.Y.S. 2d 839 (1942). 
tributees, or legatees are subject to the jurisdiction of that foreign government. ${ }^{24}$

7. The expropriating government seeks to recover a claim owed to one of its nationals, ${ }^{25}$ or asserts a lien, established on behalf of one of its nationals against property within the United States. ${ }^{26}$

The above situations, where they are sought to be affected by expropriatory decrees, illustrate that these decrees purport to regulate legal relations involving elements foreign to the legislative jurisdiction of the expropriating governments. The physical location of the tangible property, the domicile or residence of the obligor, and the law governing the legal relationship in issue, are examples of these elements. The question therefore arises whether, and if so, to what extent, the foreign government can legally affect these elements foreign to its legislative jurisdiction. In this kind of situation the relationship between a government and its nationals, based upon allegiance, ${ }^{27}$ has to be distinguished from the relationship of the national with respect to tangible and intangible property located abroad.

If all elements are localized within the jurisdiction of the expropriating government, full effect will be extended to its measures in American courts. ${ }^{28}$ But once some of the elements are not so localized, difficulties appear. A particularly troublesome question is that of the situs of intangibles. As intangibles do not have a situs in a physical sense at all, their situs is a matter of legal fiction and highly controversial. ${ }^{29}$ It seems

24 Estate of Joseph van Dam, N.Y.L.J., June 25, 1943, p. 2477, col. 7 (N.Y. Surr. Ct.).

${ }_{25}$ Matter of Breitung, N.Y.L.J., March I5, I943, p. 1029, col. 3 (White Plains Surr. Ct.).

${ }^{26}$ Birnbaum v. Irving Trust Co., N.Y.L.J., Aug. I4, I943, p. $3^{15}$, col. 2 (N.Y. Sup. Ct.).

${ }^{27}$ Cf. United States v. Curtiss-Wright Export Corp., 299 U.S. 304 (1936); American Banana Co. v. United Fruit Co., 213 U.S. 347 (Igog); Blackmer v. United States, 284 U.S. 42 I (I932).

${ }^{28}$ Underhill v. Hernandez, r68 U.S. 250 ( 1897 ); Oetjen v. Central Leather Co., 246 U.S. 297 (rgr8); Ricaud v. American Metal Co., 246 U.S. 304 (r9I8); Salimoff \& Co. v. Standard Oil, 262 N.Y. 220 , I86 N.E. 679 (I933); Luther v. Sagor \& Co., [I921] 3 K.B. 532; Prinzess Olga Paley v. Weisz, [1929] I K.B. 7 I8. These cases confirm the affirmative part of the following statement in Dicey: "A State's authority, in the eyes of other States and the Courts that represent them is, speaking very generally, coincident with, and limited by, its power. It is territorial. It may legislate for, and give judgments affecting, things and persons within its territory. It has no authority to legislate for, or adjudicate upon, things or persons (unless they are its subjects) not within its territory." Dicey, Conflict of Laws 20 (5th ed. I932). Cf. I Oppenheim, International Law 266, 507 (5th ed. by Lauterpacht, I935).

${ }^{29}$ Said Cardozo, J., in Severnoe Securities Corp. v. London \& Lancashire Ins. Co., Ltd., 255 N.Y. I 20, I23-I24, I 74 N.E. 299,300 (I93 I): "The situs of intangibles is in truth a legal fiction, but there are times when justice or convenience requires that a legal situs be ascribed to them. The locality selected is for some purposes, the domicile of the creditor: for others, the domicile or place of business of the debtor, the place, that is to say, where the obligation was 
that no uniform solution can be given to this question, for it depends upon the various objectives of the norms applicable to the particular kind of fact situation..$^{30}$

In all cases where the enforcement of an obligation is the chief objective, the situs of the chose in action must be taken to be in the country where it can be properly enforced. It is clear that two or more countries may have at the same time the legal power to compel performance of an obligation, in the sense of giving a judgment and enforcing it. The power may be based on the presence or domicile of the debtor ${ }^{3 \mathrm{x}}$ or on the location of the debtor's property within the territory of the enforcing state..$^{32}$ With respect to exchange control, the objectives of which are mainly achieved by means of compulsion upon those parties to the legal relationship, who are within the reach of the strong arm of the law, irrespective of whether they are obligor or obligee, situs of a chose in action is sometimes at the place of the obligor and sometimes at the place of the obligee, depending on who is subject to the jurisdiction of the exchange control authority. The same rules govern American Foreign Funds Control and measures of economic warfare in general. ${ }^{33}$

created or was meant to be discharged; for others, any place where the debtor can be found. At the root of the selection is generally a common sense appraisal of the requirements of justice or convenience in particular conditions." See also I Beale, Conflict of Laws 30I-302 (I935); Goodrich, Conflict of Laws I25 ff., I4I, I42, 426 ff. (r938); Powell, The Business Situs of Credits 28 W.Va. L. Q. 89, 90-9I (I922); Andrews, Situs of Intangibles in Suits against Nonresident Claimants 49 Yale L. J. 24 I (r939); note, 32 Col. L. Rev. I44I (I932); Restatement, Conflict of Laws $\$ 2$ I3 (I934).

${ }^{30}$ Situs for purposes of taxation: Blackstone v. Miller, I88 U.S. x89 (Ig03); Curry v.

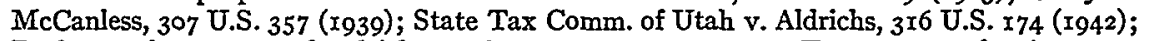
Beale, op. cit., 301-302; Goodrich, op. cit., supra, note 29, at I25. For purposes of assignment: Goodrich, op. cit., supra, note 29, at 426 ; Cheshire, Private International Law 443 ff. (2d ed. 1938); Nussbaum, Private International Law ${ }_{52} 2$ fi. (1943). For garnishment and attachment purposes: Harris v. Balk, r98 U.S. 215 (I905); Pennington v. Fourth Nat'l Bank of Cincinnati, 243 U.S. 269 (I9I7); Parker, Peebles \& Knox v. Nat'l Fire Ins. Co., III Conn. 383 (I930). For purposes of founding administration, see Baker v. Baker, Eccles \& Co., 242 U.S. 394 (I9I 7 ).

${ }^{3 x}$ See Holmes in Blackstone v. Miller, supra, note 30 , at 205: ".... What gives the debt validity? Nothing but the fact that the law of the place where the debtor is will make him pay..... Power over the person of the debtor confers jurisdiction, we repeat." Sokoloff $v$. National City Bank of New York, 239 N.Y. I58, I69, I 45 N.E. 917 (x924). See Beale, supra, note 29, at p. 304. Swiss Bank Corp. v. Boehmische Industrial Bank, [1923] I K.B. 673; Sutherland v. Administrator of German Property, [1934] I K.B. 423. Said Scrutton, L. J.: "There is considerable authority for the view that the situs is where the chose in action can be recovered, namely, where the defendant against whom the claim is made is residing" (pp. $430-43 \mathrm{r}$ ). Cheshire, supra, note 30 , at $44^{2}$.

32 Note 30 supra.

${ }^{33}$ See $\$ 5$ (b) of the Trading with the Enemy Act, as amended by the First War Powers Act I94I, and Lourie, Trading with the Enemy Act, 42 Mich. L. Rev. 205, 2I2 (r943), and "Enemy" under the Trading with the Enemy Act and Some Problems of International Law, in $4_{2}$ Mich. L. Rev. for December, I943. 
The objectives of the expropriatory decrees of the governments-inexile are dictated by the exigencies of warfare. Chief among them are: to prevent assets abroad belonging to nationals in occupied territory from falling into the hands of the enemy, to preserve these assets for their owners, ${ }^{34}$ and to utilize them for the conduct of war. ${ }^{35}$ The legal devices by which the governments-in-exile attempt to achieve these ends are the vesting of fiduciary ${ }^{36}$ or beneficial ${ }^{37}$ title in the state with respect to certain choses in action and bank accounts, by the authorization of government agencies to exerciseall the rights belonging to owners in occupied territory, ${ }^{38}$ and by requisitioning of ships. ${ }^{39} \mathrm{It}$ is interesting to note in this connection that the British Defense (Finance) Regulations, I939, as amended, ${ }^{40}$ provide, among other things, for transfer to the Treasury of securities marketable outside the United Kingdom, and among them those located abroad belonging to certain classes of British subjects or residents in the United Kingdom or of the sterling area, by way of orders and directions for a price which shall be not less than the market value. When orders or directions are given, the securities affected vest forthwith in the Treasury free from any mortgage, pledge or charge, and the owner must do all such things as are necessary, or as the Treasury or the Bank of England may direct to be done for the purpose of seeing that the securities are delivered or registered in the name of the Treasury.

Whereas the British measure acts in personam by requiring English subjects or residents to do some affirmative act, this feature is missing in the exilarchic decrees, because the affected nationals are de facto beyond

${ }^{34}$ Netherlands decrees of May 24, I940, $\S \mathrm{r}(3)$, Staatsblad Ar, and of March 6, I942, $\S \mathrm{I}(3)$, Staatsblad $\mathrm{Cr}_{1}$, and as amended by Decree of May $7, \mathrm{I}_{942}$, Staatsblad $\mathrm{C}_{34}$. Translations into English are given in Circulars 209I and 2633 of the Federal Reserve Bank of New York.

${ }^{35}$ Norwegian Provisional Order in Council, April 20, I940, $\S$ I, "for the purposes of securing supplies and furthering war operations for Norway. ...." C.C.H. War Law Serv., Foreign Supp., \#65,449.0r (1942). See also Provisional Order in Council, May I8, I940 (C.C.H. War Law Serv., Foreign Supp., \#65,449.11).

${ }^{36}$ Netherlands Royal Decrees cited supra, note 34 .

37 Norwegian Royal Decree cited supra, note 35.

${ }^{38}$ Netherlands Royal Decrees of June 7, r940, Staatsblad A6 and of January 3, r942, Staatsblad $\mathrm{C}_{2}$.

39 See supra, note 35. The Provisional Order of May r8, 1940, of the Norwegian Governmen was passed on in the Rigmor case, decided March I7, I942, by the Supreme Court of Sweden, $37 \mathrm{Am}$. J. Int. L. I4I (I943), and in the case of Lorentzen v. Lyddon \& Co., Ltd., 7 I Lloyd's List L.R. I97 (K.B. I94r). See also the Netherlands Zeeschepenbesluit I942, Staatsblad Cr7 of June 5, I942, as amended by decree of August 20, I942, C.C.H. War Law Serv., Foreign Supp., \#65,450.

${ }^{40}$ See in C.C.H. War Law Serv., Foreign Supp., under British Finance Regulations \#66,6r2. 
the reach of their sovereign. ${ }^{4 x}$ Consequently, the only way open to the latter is to attempt to reach the passive side of the contractual relationship or, in other words, the obligors in foreign jurisdictions. These obligors obviously will perform their obligations only when they are assured that the performance will result in a legal discharge of their obligations, or if they are legally compelled to do so by action of court or legislature..$^{2}$

Since these vested choses in action and bank accounts may be enforced in the jurisdiction to which the obligors are subject, ${ }^{43}$ the situs of these choses in action may in legal contemplation be deemed to be at the place of enforcement $t^{44}$ and therefore outside the territorial jurisdiction of the expropriating government. ${ }^{45}$ Consequently, it might be contended that effect should be denied to such foreign measures in American courts. ${ }^{46}$ However, moved mainly by cogent extra-legal considerations, some-

${ }_{4 \mathrm{x}}$ But compare a recent decree issued in London, by the Royal Netherlands Government on July 30 , 1943, establishing a foreign exchange institute to maintain the foreign exchange position of the Netherlands and the Netherlands East Indies. This decree purports to affect corporations which have moved to unoccupied territories and corporations still established within occupied territory whose foreign assets have been administered by officers and agents appointed or confirmed by the government. As to the problem of removal of corporate domicile see Meyer and Torczyner, Corporations in Exile, 43 Col. L. Rev. 364 (I943).

${ }_{42}$ Though the authors do not know of any such legislation with respect to property, this idea is incorporated in the Allied Forces Act, I940, $3 \& 4$ Geo. VI, c. 5I. CE. In re Amand, Nos. $I$ and 2 , cited supra, notes II and $I 8$.

${ }^{43}$ See Brandeis, J., in Security Savings Bank v. California, 263 U.S. 282, 285 (1923): "Thus the deposits are clearly intangible property within the state. Over this intangible property the state has the same dominion that it has over tangible property." Sutherland v. Administrator of German Property, [r934] I K.B. 423; Swiss Bank Corp. v. Boehmische Industrial Bank, [I923] r K.B. 673. See note, 40 Harv. L. Rev. 989, 993 (I927), where it is submitted that a transfer of bank accounts should be controlled by the law of the state where the bank is established. Cf. Restatement, Conflict of Laws $\S 5$ I, comment $b$, second sentence (I934).

44 The strongest case is presented when the intangibles are embodied in documents, e.g., in certificates of stock in an Amerícan corporation, and the certificates are located in America.

45 United States v. Curtiss-Wright Export Corp., 299 U.S. 304, 3I8 (I936); Dicey, Conflict of Laws 20 (5th ed I932). Southern Pacific R. Co. of Mexico v. Gonzalez, 48 Ariz. 260, 273, 6I P. $2 \mathrm{~d} 377,382$ (I936): "It is a general rule of international law that no law has any effect of its own force beyond the limits of the sovereignty from which its authority is derived." Restatement, Conflict of Laws $\$ \$ 47,62,63$ (I934). Hudson World Court Reports 20, 68 (I935). Cf. also Sandberg v. McDonald, 248 U.S. I85, r95 (I9r8).

${ }^{6}$ Though the validity and effect of voluntary assignments of choses in action may be governed by different laws, depending on whether the reasons for which the validity is questioned relate to capacity, formalities or essentials, two rules in general predominate. According to one, transfer is governed by the lex loci actus (place of assignment); according to the other, by lex loci contractis (meaning the proper law of the contract). However the validity and effect of an involuntary assignment appears to be determined only by the lex situs. Cf. Restatement, Conflict of Laws $\$ \S 350-354$ (I934); 2 Beale, supra, note 29, at 1250 ff.; Cheshire, supra, note 30 , at 439 ff.; Goodrich, supra, note 29,426 . See also Republica de Guatemala v. Nunez, 95 L. J. Rep. 955 (K.B. 1926). 
times called "comity," 47 and sometimes "public policy," ${ }^{8}$ courts have, to a limited extent, given effect to these expropriatory decrees where there are only slight contacts with the forum and have denied effect where the contacts with the forum are multiple or substantial.49

\section{EXPROPRIATORY DECREES AND SOVEREIGN TMINUNITY}

Expropriatory measures taken by governments-in-exile give rise to the question whether these governments, by claiming title, are thereby made necessary parties or are to be deemed the real parties in interest in the suits between private litigants involving property affected by these measures..$^{50}$ Obviously, in order to decide that the foreign government is a necessary party, the court must take a position as to the legal effect of the foreign measure in issue. For if the court determines that the foreign sovereign is a necessary party, it thereby indicates that the expropriating government's claim is so plausible, on account of the court's preparedness to extend certain effect to the expropriatory decree, that the case should not be adjudicated without the presence of that government as a party-litigant.sx In this connection it is well to bear in mind that different results will generally follow depending on whether the property

${ }^{47}$ Anderson v. N.V. Transandine Handelmaatschappij, 28 N.Y.S. $2 d 547$ at 552 (I94I).

${ }^{48} \mathrm{Ibid}$., at 553 . Lorentzen v. Lyddon, supra, note 39 : "England and Norway are engaged together in a desperate war for their existence. Public policy demands that effect should be given to this decree." As to the sense in which the term "public policy" is being used in this connection see pp. 44 and 45, infra. Cf. also United States 'v. Pink, 3I5 U.S. 203 (I942), enforcing Russian confiscatory decrees "to eliminate all possible sources of friction between these two great nations."

49 See Part IV of this article, p. 38.

so Cf. Valk v. Reilly Tar \& Chemical Co., N.Y.L.J., March ro, 1943, p. 953, col. 3 (N.Y. Sup. Ct.): N.V. Transandine v. Massachusetts Bonding Co., N.Y.L.J., March 3, r943, p. 848 , col. 7 (N.Y. Sup. Ct.).

${ }_{51}$ Cf. Lamont v. Travelers Ins. Co., 28 I N.Y. 362, 368, 24 N.E. 2d 8I (I939): "The problem is, primarily, whether the Mexican Government is a necessary party, because of its claim that it owns the fund and that none of the parties who urge conflicting claims have any legal or equitable interest in the fund and, incidentally, whether the controversy between the parties to the action involves questions upon which the courts cannot pass without invading the sovereign right of immunity of the Mexican Government." And at page 373: "The foreign government does not become a necessary party to the action unless the issues raised in the action by the pleadings of the parties in the action cannot be decided without the presence of the foreign government. No issue is raised merely by suggestion of a Government which refuses to intervene and to present proof to sustain its allegations..... The mere assertion by a foreign government, without proof, that property which is the subject of controversy between parties here belongs to the government does not constrain the court to refuse jurisdiction of the property" (italics supplied). Cf. also Aktieselskabet Dampskibsselskabet Vesterhavet v. W. A. Kirk \& Co., Inc. (Republic of Chile Appearing Specially), N.Y.L.J., Sept. I, I943, p. 433, col. 6 (N.Y. Sup. Ct.); Compania Naviera Vascongado v. S.S. Cristina, [1938] A.C. 485, 490, 516; Haile Selassie v. Cable \& Wireless, Ltd., [I938] Ch. D. 839, 844, 847. 
involved was, at the time of the promulgation of the contested measure, within the territorial jurisdiction of the foreign government ${ }^{52}$ or on the open seas, ${ }^{53}$ or within the jurisdiction of the forum..$^{54}$ It may appear that the recent decisions of the Supreme Court of the United States in the Belmont and Pink cases, ${ }^{55}$ if they do not blot out this distinction entirely, at least make it very tenuous. These cases together declare that the federal policy overrides not only state policy but also the rule of state courts concerning choice of law as to deposits in the state. However, a thorough analysis of the political and international background of these cases will reveal that the doctrines enunciated there have to be limited to the exceptional situation in which an international agreement has been concluded whereby the confiscated property within the country of the forum has been assigned to the government of the forum in satisfaction of certain claims of that government and its nationals. ${ }^{56}$

Should the foreign governments in such cases be considered necessary parties, the question may then come up whether the forum must decline jurisdiction because of sovereign immunity from suit. The problem is then shifted from the field of private to that of public international law.

The issue of sovereign immunity may be raised procedurally in the following ways:

a) by special appearance of a diplomatic representative of the foreign sovereign; ;7

b) by notice emanating from the executive branch of the government of the forum that it has recognized and allowed the claim of immunity $;^{58}$

52 See cases cited in note 28 .

53 Compania Española de Navigacion Maritima S.A. v. The Navemar, 303 U.S. 68 (I938).

54 Vladikavkazsky Ry. v. New York Trust Co., 263 N.Y. 369 , I89 N.E. 456 (I934); Guaranty Trust Co. v. United States, 304 U.S. 126 (I938); Moscow Fire Ins. Co. v. Bank of New York, 280 N.X. 286, 20 N.E. $2 \mathrm{~d} 758$ (I939), aff'd sub nom. United States v. Moscow Fire Ins. Co., 309 U.S. 624 (1940).

5s United States v. Belmont, 301 U.S. 324 (x937); United States v. Pink, 315 U.S. 203 (1942).

${ }^{56}$ For a discussion of the implications of these cases see Borchard, Extraterritorial Confiscations, 36 Am. J. Int. L. 275 (I942); Jessup, The Litvinov Assignment and the Pink Case, $36 \mathrm{Am}$. J. Int. L. 282 (I942); Chief Judge Lehman in the penultimate paragraph of the Transandine case, supra, note 22.

57 Ex parte Muir, 254 U.S. 522 (I92I); Lamont v. Travelers Ins. Co., 28I N.Y. 362, 374, 24 N.E. 2d 8I, 86 (I939). "Assertion of sovereign's immunity to suit cannot be made by private party litigant." Kunglig Jarnvagsstyrelsen v. Dexter \& Carpenter, Inc., 32 F. 2d 195, 200 (C.C.A. 2 d I929), cert. denied 280 U.S. 579 (r929). (1938).

${ }^{8}$ See Compania Española de Navigacion Maritima S.A. v. The Navemar, 303 U.S. 68 
c) by presentation of a mere suggestion of immunity to the court by the executive branch of the government. 59

Whether sovereign immunity will be allowed depends upon the nature of the interest the foreign government claims to have in the property within the jurisdiction of the forum. While in England possessory, or even a proprietary, interest ${ }^{60}$ is determinative, the touchstone in American law is whether the foreign government is in actual possession and control. ${ }^{6 r}$ Usually, possessory and proprietary interests coincide, but the reverse is true in most cases in which the extraterritorial effect of expropriatory decrees is involved. This is so because under these decrees only the title to the choses in action is purported to be vested in the expropriating authorities by the simultaneous divesting of the owners of their title. If the possession, in legal contemplation, was in the original owner, ${ }^{62}$ it remains there. Hence, it is submitted that mere change in proprietary title to an account, without more, and that by act of foreign government, does not change the possession..$^{63}$

The original owner retains this possession until one of the following three things occurs:

59 Sullivan v. State of São Paulo, I22 F. 2d 355 (I94I); Hannes v. Kingdom of Rumania Monopolies Institute, 260 App. Div. I89, 20 N.Y.S. 2d 825 (I940). Cf. also American Tobacco Co. v. Goulandris, 39 F Supp. 630 (S.D.N.Y. 194I) and 40 F. Supp. 924 (194I). As to the distinction between "recognition and allowance". and "suggestion," compare Lamont v. Travelers Ins. Co., 28I N.Y. 362, 24 N.E. 2d 8I (I939). On the implications of the latter case see Deak, The Plea of Sovereign Immunity and the New York Court of Appeals (1940), $4^{\circ}$ Col. L. Rev. 453 (1940).

${ }^{60}$ Vavasseur v. Krupp, 9 Ch. D. 35 I (I878); Haile Selassie v. Cable \& Wireless, Ltd., [I938] Ch. D. 839. Cf. also Lord Maugham in Compania Naviera Vascongado v. S.S. Cristina, [1938] A.C. 485,516 , but see Lord Wright in the same case at 506.

ox "The possession .... must be an actual possession and not that mere constructive possession which is very often implied by reason of ownership under circumstances favorable to such implication," (italics supplied) The Davis, ro Wall. (U.S.) I5, 2I (1869). Compania Española de Navigacion Maritima S.A. v. The Navemar, 303 U.S. 68 (I938). Cf. also Compania Naviera Vascongado v. S.S. Cristina, [I938] A.C. 485, 490; Bradford v. Chase Nat'] Bank, 24 F. Supp. 28 (S.D.N.Y. r938); Johnson Lighterage, No. 24, 23 I Fed. 365 (19r6).

62 Said Judge Woolsey in Bradford v. Chase Nat'l Bank, 24 F. Supp. 28 (S.D.N.Y. r938) a case in which the Philippine Government invoked sovereign immunity with respect to its bank accounts: "I have had much solicitude in determining this question of possession of the bank accounts, and have come to the conclusion that the best, if not the only, way in which the possession of a chose in action--such as a bank account-can be shown, is by showing in whose name the account stands, for the person in whose name the account stands has absolute control of it and that is all possession of a chose in action can mean."

${ }_{6}{ }_{3}$ The note, Protective Expropriatory Decrees, 4I Col. L. Rev. 1072, 1076 (I94I), discussing the possession test as to vested deposit and securities accounts fails to apply the proper analysis to these situations, as it focuses attention on the tangibles which are the objects of the choses in action and not on the choses in action themselves. 
I. The original owner recognizes or consents to the transfer of title and this is brought to the notice of the obligor ${ }^{64}$ or

2. The obligor "attorns" to the expropriating government and recognizes its rights $;^{65}$ or

3. The expropriating government reduces its right to possession through court action. ${ }^{66}$

If none of these three things has happened and possession of the chose in action has therefore not passed to the expropriating government, immunty from suit does not attach; to protect its proprietary interest the expropriating government has to intervene and voluntarily submit to the jurisdiction of the forum. This intervention may be made proprio motu or may be brought about by interpleader, or, in cases subject to the New York jurisdiction, also by the remedy provided for in Section 5 Ia of the Civil Practice Act. ${ }^{67}$

\section{THE EXPROPRIATORY DECREES in foro}

A domestic obligor, faced by conflicting demands for performance made upon him by the original obligee, his heirs, administrators, executors, or assigns on the one hand, and by the expropriating government on the other, finds himself in a quandary, as there is no legislative pronouncement as to the effect to be extended ${ }^{68}$ to the expropriatory decrees under discussion. General Ruling No. I2 of the Treasury Department ${ }^{69}$ cannot be construed as a legislative expression on that matter. ${ }^{70}$ The elimination

${ }^{6} 4$ See, e.g., the Transandine case, supra, note 47 , where the original owner of the attached property, the Transandine Handelmaatschappij, recognized that the title to the attached property had been vested in the Netherlands Royal Government pursuant to its decree of May 24, 1940.

65 This frequently occurs in practice when the vesting government settles claims originally belonging to expropriatees. However, no cases in point are known to the authors.

${ }^{66}$ Matter of Breitung, cited supra, note 25.

${ }_{67}$ The device adopted in Sec. 5 ra of the New York Civil Practice Act is a short statute of limitations. This section "was enacted because interpleader, as applied to a mere debt, has been declared to be in personam, and hence not capable of supporting service of process outside the State," said Justice Walter in Koninklijke Lederfabriek "Oisterwijk" N.V.v. Chase Nat'l Bank, 177 Misc. I86, I89, 30 N.Y.S. 2d 518, 523 (1941), adding that this declaration might well be re-examined "in the light of repeated adjudications that a debt has a situs at the home of the debtor." It was held in this case that a "fiduciary" appointed by the commissioner of the Reich for occupied territory of the Netherlands was not a claimant within the meaning of the statute, as the "fiduciary" is not a claimant other than the plaintiff in the action, and the claim that he asserted is not other than that asserted by the plaintiff.

${ }^{68}$ See note 42 , supra.

69 April 2I, 1942, 7 Fed. Reg. 299x (1942).

${ }^{20}$ Compare Domke, Trading with the Enemy in World War II ${ }_{3} 6_{3}$ (I943). 
of "the transfer by operation of law" as defined in General Ruling No. I2 from the scope of that ruling does not affect the material rights of the parties; it merely excludes such a transfer from the scope of General Ruling No. I2. General Ruling No. I2 does not purport to modify Executive Order No. 8389 as amended and it doesnot purport to determine the legal effect of any transaction, excluded from its provisions. The granting of a license or an exemption therefrom does not release the debtor from ascertaining at his own risk whether an effective transfer has occurred..$^{7 x}$ Of equally little help are the circulars transmitted to the banks by the Federal Reserve Bank at the request of the Treasury Department, pursuant to diplomatic representation made to the Department of State by the foreign representatives. ${ }^{72}$

Therefore, a prudent obligor will not undertake the risk of ascertaining for himself to what extent the decrees in question are binding upon him; he will shift that burden to the courts. From cases already adjudicated certain definite conclusions can be drawn. But before going into an analysis of the outstanding cases, it might be pertinent to consider some basic questions connected with the application of foreign decrees.

In determining the effect of a foreign decree, the existence thereof must be proved to the satisfaction of the court. The court does not take judicial notice of foreign law; it has to be proved as a fact. ${ }^{73}$ The evidence may take various forms, one of which may be a statement issued by a government agency of the forum, e.g., the State Department, based upon information given by the diplomatic representative of the foreign government. In this connection, we refer to the circulars of the Federal Reserve Bank cited above. Another may be a statement that the State Department has taken "official cognizance" of the foreign decrees. It might be appropriate to stress that such cognizance pertains only to the proof of the

7x Press Release, April 2I, 1942, No. 33, by the following quotation, substantiates this conclusion: "Of course, if an assignment would have been invalid without freezing control (e.g., because not properly executed) a Treasury license does not purport to remedy this type of invalidity." This applies with equal force to transfers by operation of law, as the Netherlands and Norwegian decrees are explicitly deemed to be by General Ruling No. I2, \$5 (e).

72 Circular No. 209r of July 2, I940, with respect to the Netherlands Royal Decree of May 24, I940, and Circular No. 2633 of June 4, 1943, with respect to the Netherlands Royal Decrees of March 6 and May 7, r942.

73 Wigmore, Evidence $\$ 255^{8}$ ( $3 \mathrm{~d}$ ed. r940). The rules for proving foreign law vary from state to state. Compare, for example, N.Y.C.P.A. \$39r with the new, very liberal New York statute adopted this year and found in Chapter 536 of the Laws of New York for I943, extending judicial notice to matters of foreign law at the discretion of the court. For the first judicial interpretation of this innovation see Abrams v. Abrams, N.Y.L.J., Nov. I2, I943, p. r3or, col. 3 (N.Y. Sup. Ct.). 
enactment of the decree, not to the effect, interpretation, or construction thereof. ${ }^{74}$

The proof of the enactment should not preclude the inquiry 'whether such enactment has taken place in accordance with the foreign legal requirements. ${ }^{75}$ To refrain from such basic inquiry because of unqualified adherence to the doctrine of the sacrosanctity of foreign acts' of state ${ }^{76}$ may lead to an anomalous situation in which our courts might give extraterritorial effect to measures which the domestic courts of the foreign governments would refuse to enforce. One aspect of this inquiry into validity should be whether the measures in issue are supported by reasonable exercise of the emergency powers of the government. Generally speaking, it is obvious that the primary aim of the vesting decrees, namely, to prevent the fall of foreign assets into the hands of the enemy, is a salutary and necessary one in the prosecution of the war. However, since United States legislation concerning trading with the enemy affords effective means of achieving the same end, particularly after the entry of the United States into the war, this raison d'être with respect to assets within the United States is questionable. "Cessante ratione, cessat ipsa lex."

Apart from their preventive aim, these vesting decrees reveal other features. For instance, the Norwegian Royal Decree aims at utilizing foreign assets for the war effort, and to achieve this end vests beneficially proprietary title in itself. ${ }^{77}$ The Royal Netherlands Decrees, as amended, ${ }^{78}$ provide for the preservation and conservation of foreign assets on behalf of Netherlands nationals, and also for restitution of the original assets or (1942).

${ }^{74}$ Anderson v. N.V. Transandine Handelmaatschappij, 289 N.Y. 9, 15, 43 N.E. 2d 502

75 See both Amand cases, supra, notes II and I8. However, up to now the American cases are still contra. Thus, Justice Shientag in the Transandine case, supra, note 47 , was satisfied with the statement of the Netherlands Minister to the effect "that the decree is a valid and binding act of the Royal Netherlands Government .... [and this] . . . . is conclusive in our courts as to the law of Netherlands."

See also Banco de Espana v. Federal Reserve Bank of New York, Ir4 F. 2 d 438 (C.C.A. 2d 1940) which held that the validity of a secret requisitioning decree of the Spanish Republican Government is not open to examination by American courts, and Fields v. Predionica i Tkanica and Yugoslav Government, supra, note Ir. Compare McNair, supra, note II, at 8o, n. 94. Eastern States Petroleum Co. v. Asiatic Petroleum Corp., 28 F. Supp. 279 (S.D.N.Y. I939) involving Mexican expropriation decree.

${ }_{76}$ Mann, The Sacrosanctity of the Foreign Act of State, 59 L.Q. Rev. 42, 59 (I943), and ibid. ad. 55 .

77 Norwegian Provisional Order of April 22, I940, §Ir, C.C.H. War Law Serv., Foreign Supp., $\$ 67,039$, providing that the rightful owners are entitled to compensation in Norwegian money within three months after recapture of the occupied territory.

${ }^{78}$ See note 34 , supra. 
their substitution within three months after the termination of the emergency, a feature which imposes on the Netherlands Government powers and duties of a fiduciary nature. ${ }^{79}$ The American Trading with the Enemy Act and the freezing orders do not provide the foreign governments with the means to achieve these complementary aims. To that extent they do not duplicate the measures contained in the foreign decrees, and therefore the latter may be deemed to be a reasonable exercise of the emergency power of the governments-in-exile.

Supposing the American court recognized the validity of the foreign decree either after the preliminary inquiry above referred to or without any inquiry at all, as the American courts have done up to now, the next inquiry will be whether the decree can affect property located within the United States. ${ }^{80}$

The decision in the Transandine case ${ }^{8 \mathrm{x}}$ substantiates the determinative effect of contacts with the forum. In that case the controversy centered around a conversion allegedly committed by a Netherlands bank in Amsterdam to the detriment of a foreign depositor who was neither a citizen nor a resident of the United States. The depositor assigned his alleged claim to a resident of New York, but for collection only, and the latter instituted a proceeding in rem by way of attachment and service by publication. The defendant Transandine appeared specially and moved to vacate the attachment and levy thereunder upon the ground, among others, that the property attached did not belong to Transandine any longer but was vested in the Government of the Netherlands, pursuant to the vesting decree of May 24, I940. The Royal Netherlands Government intervened in the proceedings and stressed the same point. Justice Shientag, by vacating the attachment, gave effect to the Royal Netherlands Decree and recognized the paramount proprietary interest of the Netherlands Government as against the plaintiff, the assignee for collection. Justice Shientag took particular care to restrict his decision to the particular facts of the case, as is apparent from the last paragraph of his opinion. The decision was affirmed by the Appellate Division and leave to appeal was granted, to bring the case on a certified question to the Court of Appeals. At this stage of the proceedings the United States attorney filed a suggestion with the Court of Appeals and submitted to it a letter of the Secretary of State formulating the views of the State Department. The Secretary of State sets forth the policy of the State Department as follows:

79 See Shientag and Lehman in the Transandine cases, supra, notes 47 and 74 .

so See Part II, supra.

${ }^{8 x} 289$ N.Y. 9 (1942). 
It is the policy of the United States that effect shall be given within the territory of the United States to that decree in so far as it is intended to prevent any person from securing an interest in, or control over, assets of nationals of the Netherlands located in the United States on account of claims arising outside of the United States in territory now or at any time under the jurisdiction of the Netherlands Government for the benefit of persons who are not at the time of their assertion citizens or residents of the United States.

Hence, it follows that, according to the views of the State Department, as they are expressed with reference to the fact situation of the Transandine case, the following elements must be present in order to give effect to the decree in question:

I. The property involved must be within the jurisdiction of the United States;

2. It must belong to persons within occupied territory;

3. Claims of third persons with respect to this property must have arisen outside the United States; and

4. These third persons must be neither citizens nor residents of the United States. ${ }^{82}$

It should be pointed out that the policy of the State Department with respect to the effect to be given to the decree is subject to revision.

Though Judge Lehman, in the decision of the Court of Appeals, does not predicate his opinion on the statement of policy as expressed by the Secretary of State, and declines to take a definite position as to whether such a statement of policy has a binding effect on state courts, ${ }^{83}$ nevertheless, he incorporates the letter of the Secretary of State into his opinion. Therefore the conclusion is justified that only in a peculiar fact situation, such as that in the Transandine case in which all four of the elements enumerated are present, will the transfer of proprietary rights to the foreign government be recognized. ${ }^{84}$ It is well to bear in mind that the only contact with the forum was the circumstance that the property attached had its situs here, whereas all other contacts were foreign to the jurisdiction.

82 The protection of interests of residents was stressed by the surrogate in the Estate of Emanuel Kahn case, 38 N.Y.S. 2d 839 (1942). See also dicta of Justice Shientag in the Transandine case, supra, note 47 , at 553 , and dicta in the Belmont case, supra, note 55 , at 332, and United States v. Manhattan Co., 276 N.Y. 396, 405, 406, I2 N.E. 2d 518, 523 (r938).

${ }^{8} 3289$ N.Y. 9, 20 (I942).

${ }_{4}$ "The Secretary points out that it would be highly desirable that this court, in deciding the present case, confine itself to giving effect to the announced policy of the United States stated in that communication [of the Secretary of State] without expressing any view with respect to the effectiveness of the decree as applied to persons and circumstances other than those referred to in the statement of policy set forth in that communication." United States Attorney's statement, 289 N.Y. 9 , at I8 (r942). 
In subsequent cases, where the contacts with the forum were more numerous or substantial, the Netherlands decree was not enforced. In a case growing out of the Transandine case, namely, Transandine v. Massachusetts Bonding, ${ }^{85}$ on an attachment bond given by the defendant Justice Shientag held that the decree was not applicable to such a situation because the claim for damages arose within the jurisdiction of the forum, and he referred specifically to Mr. Cordell Hull's statement of policy.

In a surrogate court's case, Estate of Emanuel Kahn, ${ }^{86}$ the following facts appeared. A Netherlands citizen who had considerable assets in New York banks died intestate in occupied Holland on June 30, I94I. He left two daughters, one of whom remained in Holland; the other escaped and immigrated to the United States, where she resided at the time of her father's death. The Netherlands Government attempted to enforce its vesting decree, but at the suggestion of the surrogate the government withdrew its claim and subordinated its rights to those of the public administrator. The surrogate, in addition to referring to the letter of the Secretary of State, invoked the well-established rule that the public policy of the state requires that the administration of decedents' estates be governed by the laws of the State of New York. Moreover, the surrogate's court determined that upon the final accounting of the public administrator the share of the daughter residing in the United States should be distributed to her; as to the share of the other daughter, the court ordered that it had to be further determined whether the alien property custodian or the Netherlands Government was entitled to receive it.

In Estate of Joseph van Dam, ${ }^{87}$ the testator, a Netherlands subject who died in the United States, left his estate by will to relatives in occupied Holland. He gave his executor power to retain the property during the lifetime of the distributees if in the judgment of the executor the distributees would not get the free enjoyment of their shares. The surrogate's court held this provision valid and refused to recognize any claim of the Netherlands Government to the shares, notwithstanding the provision of an amendment to the Royal Netherlands Decree and a special decree dealing with decedents' estates. In so deciding, the court gave full force and effect to the expressed will of the testator, though it realized that this provision was made to eliminate the enforcement of the Netherlands decrees.

${ }^{85}$ N.Y.L.J. March 3, I943, p. 848, col 7 (N.Y. Sup. Ct.).

${ }^{86} 38$ N.Y.S. $2 d 839$ (I942).

87 N.Y.L.J., June 25, I943, p. 2477, col. 7 (N.Y. Surr. Ct.). 
It will readily be seen that in the cases of Estate of Emanuel Kahn and Estate of Joseph van Dam there was no need whatsoever for a fiduciary management or administration of the decedent's estate by the Netherlands Government since such administration is provided for by the legislation of the country of the forum or by the will expressly manifesting the intent of the testator, to which intent the courts give precedence.

It is worthy of note that up to the present time the effect of foreign expropriatory decrees has not been judicially determined in a pure case of conflicting interests between the divested owner and the vesting government.

One of the motivating reasons for extending a certain limited effect to the Netherlands decree in the Transandine case was that such effect is in conformity with the "public policy" of the freezing regulations and corollary state measures-according to Justice Shientag ${ }^{88}$-and in accordance with the public policy of the state-according to Chief Judge Lehman. ${ }^{89}$ It seems that Lehman based his opinion on much narrower grounds than Shientag, for Lehman wanted to leave the issue open whether the State Department can formulate a policy binding upon the state when it is not in furtherance of an international agreement.90 On the other hand, Shientag has gone too far in his willingness to detect a national policy at a time when such a policy has not yet been defined by the national government, as appears from Mr. Cordell Hull's letter referred to above. ${ }^{91}$ The expression, "public policy," in this connection may lead to confusion as it is not used in the sense commonly accepted in the field of conflict of laws. For in conflict of laws "public policy" is used as a device which enables the court to deny effect to foreign law when this law is repugnant to basic ideas and ideals of the legal and economic system of the forum; ${ }^{22}$ in other words,

${ }^{88} 28$ N.Y.S. $2 d_{547}, 553,558$ (r $\mathrm{r}_{94 \mathrm{r}}$ ).

${ }^{89} 289$ N.Y. 9,20 (1942). See also the contention of the counsel for the Netherlands Government in the Estate of Emanuel Kahn case, 38 N.Y.S. 2d 839 at 842 (I942).

90 Ibid, at 20.

9x Point IV of United States Attorney's suggestion incorporated in the Court of Appeals opinion in the Transandine case, 289 N.Y. $9, \mathrm{r} 6$ and $\mathrm{r}_{7}$ ( $(942)$. Cf. Kuhn, The Effect of a State Department Declaration of Foreign Policy upon Private Litigation, 36 Am. J. Int. L. 651 (1942).

92 For the best judicial expression see Cardozo in Loucks v. Standard Oil Co., 224 N.Y. 99, III, I20 N.E. $x_{98}$ (Igr8). Generally foreign penal and fiscal laws and laws in furtherance of governmental interests of other states are denied enforcement by the forum, though not always express reference to "public policy" is made. See also Nussbaum, Public Policy and the Political Crisis in the Conflict of Laws, 49 Yale L. J. I027 (I940); Nussbaum, Principles of Private International Law, §12, pp. I Io ff. (1943); Husserl, Public Policy and Ordre Public, 25 Va. L. Rev. 37 (1938); Restatement, Conflict of Laws §6ro (I934); Leflar, Extrastate En- 
the "public policy" is the safety valve on the engine of comity which moves the court to apply the foreign law.93 "Public policy," however, as it is used in the Transandine case, instead of operating as a safety valve, acts as an accelerator. ${ }^{94}$ In other words, it was used in the sense common in the field of statutory interpretation, in order to apply such a construction, out of many possible ones, which best effects the legislative intent. But even resort to "public policy" in that sense might inhibit enforcement of a foreign decree, if such enforcement would run counter to the legislative intent as expressed in statutory enactments. We are thinking here of a possible conflict between the vesting order of the alien property custodian and the vesting decrees of foreign governments. ${ }^{95}$

\section{PROBLEM OF "DOUBLE IIABIIITY"}

Another aspect of the extraterritorial effect of foreign expropriatory decrees which should not be neglected is that of "double liability." Unfortunately, it can not be fully treated here because of space limitations.

The question of double liability may arise when an obligor follows the instructions of the original owner whose claim is vested in the government, or when it follows the instructions of the expropriating government. Though, to the knowledge of the authors, only one case squarely in point

forcement of Penal and Governmental Claims, 46 Harv. L. Rev. 193 (1932). See Dicey, Conflict of Laws 212 (5th ed. 1932); Cheshire, Private International Law c. v, pp. 133-I54 (2d ed. 1938). For a very recent judicial expression of non-enforcement of revenue laws see Estate of Emest Daltroff, N.Y.L.J., June I7, r943, p. 2369, col. 3 (N.Y. Sup. Ct.).

93 Cf. Estate of Emanuel Kahn, 38 N.Y.S. 2d 839 (I942), where "public policy" was resorted to, to deny effect to the Netherlands vesting decrees in order to protect the rights of domestic creditors, next of kin, and legatees of the estate. It should be borne in mind, however, that, even though the forum has a law similar to those the recognition and enforcement of which is in issue, it still may refuse extending effect to the foreign laws as is best exemplified by the line of cases here and on the Continent dealing with foreign exchange restrictions. See Mann, The Legal Aspect of Money 259 (1938); Nussbaum, Public Policy and the Political Crisis in the Conflict of Law, 49 Yale L.J. I027, I047, I05I (1940); Domke, supra, note 70 at 33I ff.; Freutel, Exchange Control, Freezing Orders and the Conflict of Laws, 56 Harv. L. Rev. $3^{\circ}$ (1942). For a very recent decision taking the same position, involving Swiss foreign exchange legislation, see International Investment Co. S.A. v. Swiss Bank Corp., N.Y.L.J., August 15, 1942, p. 355, col. 7 (N.Y. Sup. Ct.). The case of Bercholz v. Guaranty Trust Co. of New York, N.Y.I.J., Aug. II, I943, p. 290, col. 5 (N.Y. Sup. Ct.) seems to be contra, but can be explained on other grounds. Vesting decrees which purport to furnish the governments with foreign funds and provide for compensation in domestic currency reveal affinity with foreign exchange regulations.

94 Cf. Mann in his annotation on Lorentzen v. Lyddon \& Co., Ltd., under Extraterritorial Effect of Confiscatory Legislation, 5 Mod. L. Rev. 262 (I942).

${ }^{95}$ See Lourie, 'Enemy' 'under the Trading with the Enemy Act and Some Problems of International Law, Part II, point D, to be published in the December, I943, Michigan Law Review. 
has been reported, ${ }^{96}$ there are indications in other cases that the fear of double liability - which was the motivating cause inducing obligors to let the controversies be submitted to the courts ${ }^{97}$-was influential in the adjudication thereof..$^{8}$ But even acting pursuant to the court's order does not free the obligor from double liability. This is so, since one of the possible claimants whose claim has not been allowed could sue even in an American court if he has not been a party to the original suit, or before the courts of another country if there, are sufficient contacts to invoke the jurisdiction of the latter. It is conceivable that the expropriating government whose claim has been disallowed may attach property of the bank within its own jurisdiction after reoccupation of its territory.

In this connection reference is made to federal and state statutory enactments which were designed to alleviate the danger of double liability of ordinary obligors ${ }^{99}$ and particularly of banks. ${ }^{\text {Too }}$ However, it must not be overlooked that these statutes do not afford full protection from this risk. ${ }^{\text {Ior }}$

${ }_{96}^{6}$ Matter of Breitung, N.Y.L.J., March I5, x943, p. 1029, col. 3 (White Plains Surr. Ct.) involving an accounting proceeding of an estate in which the accountant was directed to pay to the Netherlands Shipping and Trading Commission, an agency of the Royal Netherlands Government, the balance of a certain fund upon the execution and delivery by it of an indemnity agreement against any liability resulting from such turning-over of the fund.

97 See, e.g., Koninklijke Lederfabriek "Oisterwijk" N.V. v. Chase Nat'l Bank, I77 Misc. 186, 30 N.Y.S. 2d 518 (194I) and Amstelbank, N.V. v. Guaranty Trust Co. of New York, 177 Misc. 548 (I94I) and Birnbaum v. Irving Trust Co., N.Y.L.J., Aug. 14, I943, p. 315, col 2 (N.Y. Sup. Ct.).

$9^{8}$ Bercholz v. Guaranty Trust Co. of New York, N.Y.L.J., Aug. II, I942, p. 290, col. 5 (N.Y. Sup. Ct.), where, in an action by a French depositor in the Paris branch of the defendant bank to recover securities kept at the main office in New York in the name of the Paris branch, the complaint was dismissed on the ground of the remote possibility that the branch might be called upon at some future date by the then recognized French government to effect the repatriation of the securities involved, which might result in a liability of the defendant through its branch in case of non-performance. This decision seems to be in certain conflict with the case of Feuchtwanger v. Central Hanover Bank \& Trust Co., 288 N.Y. 342, 43 N.E. 2d 434 (1942).

99 N.Y.C.P.A. $\$ \$ 5$ ra, $287 \mathrm{a}$ and e.

${ }^{100} 54$ Stat. I79, I2 U.S.C. $\$ 95 a, \S 632$ (r94I) and New York Banking Law $\$ \S ~ I 34(7)$ and $\mathrm{r}_{3} 8$. (Laws of New York I94I, c. I50, in effect since March 24, I94I, known as the "Williamson Act.")

Ior Whether $\$ \mathrm{I}_{34}(7)$ and $\mathrm{r}_{3} 8$ of the New York Banking Law are applicable also to national banks is still undecided, but compare dictum of Justice Walter in Koninklijke Lederfabriek, "Oisterwijk" v. Chase Nat'l Bank, I77 Misc. I86, r94, 30 N.Y.S. 2d 51 8, 527 (r94I): "The conclusion thus reached makes it unnecessary to consider whether or not there can be applied to a national bank the provisions of Chapter I5O of the Laws of I94I, effective March 24, I94I, by which Section I34 of the Banking Law is amended so as to provide, in general, that a bank or trust company need not recognize or give effect to claims, advices, statutes, rules or regulations emanating from territory dominated by authority not recognized by the United States as the de jure government of such territory. Whether technically applicable or not, that enactment 
Should an expropriating government be willing to deliver an indemnity agreement to an obligor, saving it harmless against double liability, ${ }^{\text {,02 }}$ it is well to bear in mind that such an agreement is not legally enforcible against that government in American courts, as it imposes an engagement of honor only ${ }^{\mathrm{x}}{ }^{3}$ However, in the majority of European countries the expropriating governments could be sued in their own courts on such an obligation. In general a judgment against such government would be, not in terms of United States dollars, but in local currency, and in addition thereto would probably be subject to currency restrictions, not to speak of difficulties incident to an execution of a judgment against a sovereign. The posting of a bond by an American bonding company would not produce a more desirable result, as it would be tantamount to a shifting of the difficulties from the bank to the bonding company.

\section{CONCLUSIONS}

The problem of the extraterritorial effect to be given to expropriatory decrees of governments-in-exile, having emerged as a consequence of the extraordinary international situation, cannot be solved by strict adherence to legal maxims such as "foreign acts of state are sacrosanct" on the one hand, and "no recognition or enforcement of foreign penal, fiscal, and political laws" on the other. These maxims, being shorthand statements containing the essence of legal thought distilled under conditions entirely different from the present, are, because they are generalizations, inadequate to cope with the intricate problems coming at present before the courts. It is submitted that the courts of this country and England have generally succeeded in striking an even balance between the principles expressed by these two maxims, at the same time paying lip service to both maxims in one or another form, frequently in one and the same case. In so doing the courts are led by the consideration of the furtherance of the interests of their own states viewed in the broader aspects of the combined allied war effort.

The resort to the expression "public policy" in order to give effect to the decrees is rather significant from the viewpoint of semantics. However, as soon as local interests conflict with the enforcement of the de-

certainly is a strong legislative declaration recognizing and confirming what I have found to be the law of New York as expressed in decisions of its courts, the applicability of which to national banks located in this state cannot be doubted."

${ }^{302}$ See in the Matter of Breitung, supra, note 96.

${ }^{203}$ Twycross v. Dreyfus, 36 L.T.R. 752, 755 (I877), per Jessel, M.R.; Lamont v. Travelers Ins. Co., 28 I N.Y. $362,372,24$ N.E. 2 d 8r, 84 (x939). 
crees, the courts, invoking "public policy" in the conflict of laws sense, refuse to give effect to the foreign decrees.

Therefore when obligees who are citizens or residents of the United States assert their rights, liens, or claims with respect to property within the jurisdiction of the forum and belonging to their obligors in occupied territory, the title of the expropriating governments is subordinated to these claims. The authors submit that similar subordination should follow when the original obligee becomes a resident of the United States after the vesting has taken place.

With respect to property belonging to persons still within occupied territory and as to which no adverse claim has been asserted by American citizens or residents, there seems to be no objection to recognition of the conservatory objectives of the foreign vesting decrees, provided, however, the paramount interests of the United States are not prejudiced thereby. The strongest expression of recognition of title is to be found in the leading New York case of Anderson $v$. Transandine. ${ }^{\mathbf{1 0} 4}$ But this case in fact did not go so far as to allow the Netherlands Government to reduce its title to possession, as a decision on this point was not necessary to the adjudication of the controversy. The English case of Lorenizen 7 . Lyddon, ${ }^{\text {105 }}$ however, relying upon Justice Shientag's opinion, decided this point in favor of the expropriating Norwegian Government.

Should assets within this country, vested pursuant to the expropriatory decrees discussed above, be the subject matter of an international agreement to which the American and expropriating governments are parties, the effect to be extended to these decrees might be of a scope more comprehensive than heretofore, as is manifest from the Belmont ${ }^{\mathrm{x} 06}$ and $P i n k^{\mathrm{x} 07}$ cases.

304 Supra, notes 22 and 47.

${ }^{105} 7$ I Lloyd's List L.R. I97 (K.B. I94I).
${ }^{106}$ Supra, note 55.

307 Ibid. 